\title{
The Enlightenment of the Education Idea of National Southwest Associated University to the Method of Ideological and Political Education in Colleges and Universities
}

\author{
Bao Liu ${ }^{1}$, Hongyun Guo ${ }^{2 *}$ \\ ${ }^{1}$ School of Automsotive and Transportation Engineering, Shenzhen Polytechnic, Shenzhen 518055, China. \\ ${ }^{2}$ School of Jewelry, Shenzhen Institute of Technology, Shenzhen 518116, China \\ E-mail: guohongyunssti@126.com
}

\begin{abstract}
The National Southwest Associated University (Lianda) was born in Kunming, Yunnan Province and brought the force of the Peking University, Tsinghua University and Nankai University during Sino-Japanese War. As a temporary university living only eight years, it cultivated lots of professionals in all areas during hard years. Lianda provided some unique educational ideas and ideological and political education methods for the higher education.

Keywords: education idea, The National Southwest Associated University, ideological and political education
\end{abstract}

The ideological and political education method is the way adopted by educators in the process of ideological and political education. In order to achieve the educational purpose of cultivating students, the working methods adopted by educators are very important. During the hard eight years of the Sino-Japanese War, Lianda had cultivated a large number of outstanding talents and built a monument in the history of higher education. Its unique educational concept and rich ideological and political education methods provided some enlightenment for the high education of modern university. Its unique educational value had deeply influenced the reform and development of higher education.

\section{Democratic and theoretical education methods}

The National Southwest Associated University was firstly established in Changsha named National Changsha Temporary University. After a semester, it moved to Kunming and was renamed the National Southwest Associated University. Lianda brought together the forces of the National Tsinghua University, the National Peking University and the Nankai University. There were lots of famous professors of Peking University, Tsinghua University and Nankai University.

Lianda's faculty was cosmopolitan and most scholars had a thorough knowledge of both Chinese and Western. ${ }^{[1]}$ Most of professors had studied abroad and had a high degree of proficiency in English. Some of them could taught students the methods of scientific research in foreign countries. They had made outstanding achievements and shared the fruits of research with students. The National Southwest Associated University cultivated excellent students, which had a close relationship with the enlightened educational thought of Lianda. The National Southwest Associated University had fully carried the spirit of academic democracy and compatibility.

The professors from different schools and backgrounds expressed their academic opinions in the class. The scholars were able to contend and bloom in Lianda's free and tolerant atmosphere, which not only aroused the enthusiasm of professors, but also opened students' eyes. It was helpful to cultivate students' speculative ability.

Some lessons were taught by professors with different teaching methods at the same time, so students could experience the master from different angles. Wu Han and Lei Haizong taught the general history of China in the College of Arts and the College of Science respectively. Their teaching style and methods are different.

Lei Haizong had amazing memory and taught in class without lecture notes. ${ }^{[1]}$ When he talked about the emperor, ministers and other historical details, he was like a master of architecture to the historical materials. Students had strong memories of Lei Haizong's lecture outline details.

Wu Han taught general history of China, economic history of Song-Yuan-Ming period. ${ }^{[1]}$ Wu Han made pointed comparisons between the past and the present. He contrasted sharply with those of his conservative old colleagues. His course was full of sarcasm, attracting hundreds of students, including those who had not taken his course. Only could the canteen had accommodated excessive students. Wu Han was able to attract students by his pedagogical skills and political appeal.

Proof of the ability of budding scientists to blossom in wartime are two Lianda students who won the Nobel Prize in physics in 1957 - Yang Zhenning (C.N.Yang) and Li Zhengdao (T.D.Lee) ${ }^{[2]}$ They received good systematic theoretical 
training in National Southwest Associated University. In the 1945, Yang Zhenning entered the University of Chicago to study theoretical physics which represents the highest level of physics in the world. He was surprised to find that the University of Chicago classroom had not taught much more than he had learned in Lianda. The physics lessons were much harder and more in-depth than which of United States. He had laid a solid foundation of theoretical physics conceptual things in National Southwest Associated University and could even point out teachers' mistakes. Li Zhengdao also gave a high appraisal to the education in National Southwest Associated University. ${ }^{[2]}$ He recalled that when he arrived in the United States, except for the latest modern physics at that time, he had learned almost all physics.

Their experience suggested that Lianda's particular strength was its ability to apply traditional pedagogical techniques to the modern sciences. Teaching methods in Lianda learned somewhat toward rote learning, but students mastered the basics in contrast to American students.

\section{Social practical education method}

The practical education method is to organize and guide student to actively participate in various practical activities. And students can develop a world view of patriotism in the process of social practice. National Southwest Associated University focused on training students' ability to go deep into society, investigate to solve social problems. In 1938, when the National Southwest Associated University moved to Yunnan, it organized more than 200 teachers and students to form a walking group, walking about 1300 kilometers for 68 days. ${ }^{[3]}$ Lianda's long march created a miracle in the history of Chinese education. The journey to the west is long and difficult. Teachers and students investigated the local customs, rivers and mountains along the way and they felt suffering of the people along the way. The students became acutely aware of the country's vastness and beautiful motherland of China. The walking group was warmly welcomed by the people all over the country. ${ }^{[3]}$ All these social realities had inspired the young students of National Southwest Associated University to study hard in the hard years. Lianda' long march was central to the spirit of Lianda and the long march was an epic pilgrimage for students. Followed by eight years of tribulation, it symbolized the ability of China's intellectual community and consequently its higher education and culture to endure. It also became the support of strong spiritual motivation for students to serve the country.

With some three thousand students enrolled in five colleges, the National Southwest Associated University was the largest and most comprehensive wartime universities. The students of Lianda always payed attention to the nation, when the Sino-Japanese War became serious. There were more than 1000 students directly serving the army. The students also went to the countryside and went down to the factory many times to fight against Japan. They performed dram and screened films to carry out patriotic movement activities in the suburbs of Kunming. They organized the service team to the Yi nationality area and carried investigation. Wen Yiduo was inspired by the minority nationality dance after watching, and wrote "Suspense of Ancient Song and Dance Drama 'Nine Songs".

\section{Typical education method with teachers as an example}

Typical education is also called demonstration education. It is a method to educate people to improve their ideological understanding through typical people. In higher education, as the main body of education, the professor is of great significance to the students' teaching. President Mei Yiqi had a famous "travel theory". The school is also like water; teachers and students are also like fish. Big fish could guide small fish.

Professors were the backbone of the National Southwest Associated University. It is believed that professors should have a broad mind and deep feelings. President Mei Yiqi insisted on the idea of "Professor teaching and running the school". ${ }^{[2]}$ He thought professors were the main body of the school and the principal was just leading the staff to serve the professors. The National Southwest Associated University was born naturally noble and constituted of Peking University, Tsinghua University, Nankai University. There were their own characteristics with more than 170 professors, a group of academic celebrities gathered together. The professors of the National Southwest Associated University had unique personality and excellent knowledge on teaching and scientific research. Professors all had deep academic attainments, and strong patriotic professionalism.

Professor Zhu Ziqing taught Song poetry and literary studies. His teaching was seriously and had strict requirements for students. ${ }^{[2]}$ Sometimes he asked students to answer or explain poetry and sometimes sent papers in class for test. All answers must be carefully reviewed and graded.

Wu Dayou, a well-known physicist who trained Yang Zhenning and Li Zhengdao. He moved to the suburbs because of air raid and stayed away from the school for more than ten miles. ${ }^{[2]}$ In order to ensure good teaching results, he never took a continuous hours teaching. He must come to school three times by horse a week for hours of hard work. 
Therefore, the education is preaching and teaching to solve doubts. The spread of Taoism is more important than the saying. At the same time, the professors of National Southwest Associated University insisted on strict teaching and sowing the fire of spreading education. Students naturally dared not to be lazy and naturally tried their best to worked hard. Although located in the home front of the war, the whole campus of the National Southwest Associated University was full of vitality and fighting spirit. Teachers and students were full spirit of exhilarating. The writer Lin Yutang once sang the praises of the students of Lianda and the spirit of Lianda.

\section{Unique teahouse culture}

In the home front of the War of Resistance, the material conditions of the National Southwest Associated University were very scarce. The supply of electricity in school buildings could not be fully guaranteed. From the beginning of the migration, it was difficult for students to find a quiet and bright place to study. Small classrooms were full of people everywhere. The light in the dormitory was dim and three or four kerosene made the light very weak. Students could not even find clothes in the dormitory and could not read and write.

The library of Donglu Institute of Technology was equipped with four large gas lamps, which were particularly bright and attracted students to study. Before the final examination, the number of students studying in the library increased greatly, and library could not accommodate a large number of students. Many students need to find somewhere else to prepare the exam.

The teahouse culture of Kunming owned a strong characteristic of the time. Teahouse also had a unique feature which prevailed the political, economic and cultural of the local culture in war time. Kuming teahouse always maintained a strong vitality. The teahouse could meet people's needs constantly and the culture of teahouse already thorough popular feeling. The teahouse also had social and cultural function such as dealing with disputes, expressing personal emotions, trading commodities and so on. Teahouse became the center of the people daily life and it could show the cultural life of Kunming folks in all levels. This is the reason why teahouse were so popular. There were more than 50 teahouses near the Lianda west gate. These teahouses were very small and could only accommodate more than a dozen guests. It was a good place to read, write and chat. Two or three friends could share a pot of tea until the teahouse proofing. Tea waiters in the teahouse were of Kunming people's unique hospitality and show warm hospitality to these students. ${ }^{[2]}$ Teahouse timetable strictly followed the school calendar. The teahouse during the eve of examination were quiet and even the noise of needle falling to the ground could be heard. The library on holiday was also closed and students had nowhere to go. Teahouse was actually the only place where you can read at night.

In the green tea's fragrance of Kunming, students read, think or argue fiercely in the teahouse. Yang Zhenning recalled that in the teahouse he and his classmates often had a fierce discussion over some problems of physical quantum mechanics. ${ }^{[2]}$ They would not stop until the teahouse proofing. Such argument were of great benefit to deepen the understanding of theoretical physics.

Wang Cengqi, a student and famous writer of National Southwest Associated University, had written a special article on the influence of teahouse culture on Lianda students. He believed that teahouse culture could improve student's magnanimity. ${ }^{[2]}$ Many students were in a state of utter poverty. However, they were positive and optimistic despise vulgarity, and maintained intellectual elegance. Many student's papers and reading reports are written in the teahouse.

\section{Unique educational value and thought}

Since twenty-first century, the reform of higher education has become an important direction of education reform, but also very difficult. The higher education of our country is developing rapidly, with the increasing demand for talents, higher education faces to more and more attention, its problems are more and more. With the development of economy and society, the trend of economic globalization and the diversity of values is obvious. Various trends of thought are constantly colliding with each other. The traditional ideological education has also been greatly challenged in the modern society. As an important part of quality-oriented education, ideological and political education needs innovation. Higher education workers should think deeply and innovate their working methods to meet the needs of the changing educational environment and educational objects. In the southwest of the general assembly in just nine years, in the idea of academic freedom, professor and students of Lianda had achieved fruitful results and created the miracle of China and even world history of university education.

\subsection{Management by professors}

Management by professors is a traditional management concept. The National Southwest Associated University had 
implemented the management by professors and professors had very high prestige in the school management. It helped to form good academic freedom atmosphere. Educating process is a dynamic system composed of three basic factors: teachers, students and teaching materials. In the whole educating process, the professor is the designer and executor of teaching activities and is in the core position of teaching. Professors have a strong influence on students. Only through professor's teaching activities, can the relevant teaching contents be changed into student's spiritual wealth. The key to the success of National Southwest Associated University is that there were a group of masters. They were knowledgeable and naturally became moral models for students.

\subsection{Strengthen the social practice education}

Social practice plays an irreplaceable role in high education. In this paper, the author points out that the Long March and teahouse culture can broaden student's horizon and rich their after-school life. Social practice can improve the quality of the students and enhance their patriotic enthusiasm. Ideological and political education based on social practice has natural advantages. However, the form of ideological and political education is single and college students' awareness is insufficient during college students' social practice. The school management department should put forward specific measures to improve student's practical educational activity and to promote ideological and political education function in practice.

\section{References}

[1] John Israel. Lianda: A Chinese University in War and Revolution. Palo Alto: Stanford University Press; 1998.

[2] Beijing Alumni Association of Southwest Associated University. History of National Southwest Associated University from 1997 to 1946. Beijing: Peking University Press; 2006.

[3] Zhang Jiqian. March of the National Southwest Associated University. Beijing: New Star Press; 2010. 